\title{
Prebiotics supplementation improves the endothelial dysfunction in n-3 PUFA-depleted $\mathrm{ApoE}^{--}$mice
}

\author{
Emilie Catry ${ }^{1}$, Géraldine Rath², Barbara D Pachikian', Audrey M Neyrinck', Patrice D Cani ${ }^{1}$, Chantal Dessy², \\ Nathalie M Delzenne ${ }^{1 *}$
}

From Genes and nutrition, is personalised nutrition the next realistic step?

Brussels, Belgium. 25 April 2014

\section{Background}

Our previous studies demonstrated that dietary n-3 polyunsaturated fatty acids (PUFA) deficiency promotes the development of non-alcoholic fatty liver disease in mice, and that modification of gut microbiota composition by prebiotics (non-digestible fructans) can improve the hepatic steatosis and serum lipids in this model $[1,2]$. The present study has been designed to analyze the potential involvement of prebiotic supplementation on endothelial dysfunction in n-3 PUFA-depleted ApoE knock-out mice.

\section{Material and methods}

Wild-type (WT, $\mathrm{n}=6)$ and $\mathrm{ApoE}^{-1-}(\mathrm{KO}, \mathrm{n}=6)$ mice were fed with a n-3 PUFA-depleted diet for 12 weeks. Fifteen days before the end, WT $(n=3)$ and KO $(n=3)$ mice were supplemented with fructans as prebiotics (PRE). Second and third generation mesenteric arteries were isolated and mounted on a wire myograph. After normalization, arteries were contracted with a $\mathrm{KCl}$-enriched $(50 \mathrm{mM})$ solution. The endothelial-dependent relaxation was evaluated after addition of increasing doses of acetylcholine.

\section{Results}

The analysis of morphological parameters showed that mesenteric micro-arteries isolated from n-3 PUFA depleted-KO mice supplemented with PRE (KO-DEFPRE) present an significant increasing by $20 \%$ in mean diameter and develop also an significant increasing by

\footnotetext{
* Correspondence: nathalie.delzenne@uclouvain.be

'Metabolism and Nutrition Research Group, Louvain Drug Research Institute, Université catholique de Louvain, Brussels, Belgium

Full list of author information is available at the end of the article
}

$35 \%$ in the basal tone compared to vessels from other groups (KO-DEF or WT-DEF). Similarly, KO-DEF-PRE micro-arteries contracted significantly more to $\mathrm{KCl}$ enriched solution than vessels isolated from other groups. Finally, we measured the relaxation evoked by acetylcholine: KO-DEF-PRE micro-arteries relaxed significantly more compared to KO-DEF mice isolated micro-arteries $(61.27 \pm 0.343 \% \mathrm{KCl} \max$ vs $80.513 \pm 2.542$ $\% \mathrm{KCl} \max , \mathrm{p}<0.01)$. This effect was blunted in the presence of COX inhibitor, indomethacin.

\section{Conclusion}

Our results suggest that fifteen days of prebiotic supplementation is sufficient to alter morphological and contractile parameters in the mesenteric bed. Importantly, prebiotic supplementation is also able to prevent the endothelial dysfunction observed in KO-DEF mice, independently of the contractile modifications. Results obtained in the presence of indomethacin appoint prostanoids as possible molecular targets, in addition to the NO/NOS pathway. Further analyses are now performed to relate changes in gut functions to cardiovascular alterations.

\section{Competing interests}

The authors declare there is no conflict of interests.

\section{Acknowledgements \\ This work was supported by the FRS-FNRS (Fonds de la Recherche Scientifique) (Convention1.5121.12)}

\section{Authors' details}

${ }^{1}$ Metabolism and Nutrition Research Group, Louvain Drug Research Institute, Université catholique de Louvain, Brussels, Belgium. ²Pole of Pharmacology and Therapeutics, Institut de Recherche Expérimentale et Clinique, Université catholique de Louvain, Brussels, Belgium. 


\section{References}

1. Pachikian BD, Neyrinck AM, Cani PD, Portois L, Deldicque L, De Backer FC, Bindels $L B$, Sohet FM, Malaisse WJ, Francaux $M$, et al: Hepatic steatosis in n-3 fatty acid depleted mice: focus on metabolic alterations related to tissue fatty acid composition. BMCPhysiol 2008, 8:21.

2. Pachikian BD, Essaghir A, Demoulin JB, Catry E, Neyrinck AM, Dewulf EM, Sohet FM, Portois L, Clerbaux LA, Carpentier YA, et al: Prebiotic approach alleviates hepatic steatosis: implication of fatty acid oxidative and cholesterol synthesis pathways. Molecular nutrition \& food research 2013, 57(2):347-359.

doi:10.1186/2049-3258-72-S1-05

Cite this article as: Catry et al:: Prebiotics supplementation improves the endothelial dysfunction in $\mathrm{n}-3$ PUFA-depleted $\mathrm{ApoE}^{-/-}$mice. Archives of Public Health 2014 72(Suppl 1):05.

\section{Submit your next manuscript to BioMed Central} and take full advantage of:

- Convenient online submission

- Thorough peer review

- No space constraints or color figure charges

- Immediate publication on acceptance

- Inclusion in PubMed, CAS, Scopus and Google Scholar

- Research which is freely available for redistribution

Submit your manuscript at www.biomedcentral.com/submit 